\title{
SURVEY OF HERBACEOUS WEED FLORA GROWING IN DAUND TAHSIL FROM PUNE DISTRICT (M.S.), INDIA.
}

\author{
Jalindarnath G. Bagal \\ Department of Botany, E. S. Divekar College, Varvand, Tal- Daund, Dist- Pune - \\ 412215, (M.S.), India. \\ Email- bagaljg@gmail.com
}

Communicated: 24.02 .21

\begin{abstract}
:
Herbs are major components of plant diversity and are an important segment of global biodiversity. The weeds are uninvited guests in any cultivated fields, gardens, and non-irrigated places. Weeds are an excellent example of the successful struggle for existence. The agro ecosystems show association of various types of native and invasive weeds in crop plants. Weeds can be defined as the plant growing in the wrong places from farmer's point of view. In present paper attempts were made to survey the herbaceous weed flora growing in Daund Tahsil from Pune district (M.S.) India. Daund Tahsil enriches with herbaceous weed flora about 60 different species of 27 families. Each plant is studied with respect to its botanical name, local name, family name, morphological characters and flowering and fruiting period. Weed species belonging to Asteraceae, Poaceae and Amaranthaceae families are dominant in this region. Some of dominant weed species are Alternanthera sessilis (L.) R. Br, Boerhavia erecta Linn. , Cynodon dactylon (L.) Pers., Cyperus rotundus L. etc.
\end{abstract}

Keywords: Survey, Weed Flora, Herbaceous, Daund Tahsil.

\section{INTRODUCTION:}

Herbs are major components of plant diversity and are an important segment of global biodiversity. Weed is a plant growing where it is not desired. Weeds can be defined as the plant growing in the wrong places from farmer's point of view. In contrast to the cultivated plants, the weed is the invader an uninvited guest in any agricultural fields. Weeds are an excellent example of the successful struggle for existence. Out of 3, 00,000 plant species known in the world, about 30,000 are weeds. Most of the weeds are herbs. Weed flora of agricultural fields has large ecological amplitude, so they multiply and flourish well even in changed environmental conditions. The invasive weeds infesting the irrigated and non-irrigated agricultural fields and other ecosystems, the associations of various types of native and invasive weeds in crops and barren lands have become a serious problem today.

Weeds compete with crops in which they grow for their resources like air, water, sunlight, minerals and other soil contents etc. ultimately this results in less crop yield, poor quality of agricultural produce by way of admixture and adulteration with weed seeds etc. and consequently in less market value. Besides, weeds inflict allopathic effects on crop plants which are large through their depressive root exudates. In addition weeds also being hosts to several pathogens and other insect pests which are considered to be the natural enemies during the development of agricultural crop plants. The present investigation related to survey of weed 
flora growing in Daund Tahsil from Pune district (M.S.), India.

Daund Tahsil lies in Pune district situated on the margins of Bhima River. Daund Tahsil consists of 102 villages and one urban centre. Geographically this region extends from $18^{\circ} 18^{\prime}$ to $18^{\circ} 41^{\prime}$ North Latitude and $74^{\circ} 07^{\prime}$ to $74^{\circ} 51^{\prime}$ East Longitude (Map-1). The geographical area of the study region is $1289.86 \mathrm{Sq}$. Km. (128986 hector) according to 2011 census. The average height of study area is 554 meters from mean sea level. The river 'Bhima' and its tributary rivers 'Mula' - 'Mutha' are dominating drainage pattern in study region. Agriculture is predominant in Daund tahsil and it provides livelihood to $66.93 \%$ population. Sugarcane is one of the important cash cros in Daund tahsil. The farmers are generally reluctant in cultivation of pulses, grams and vegetables. Therefore the acreage under above crops is declined largely in study area. Total area under cultivation is 103844.94 hectares in Daund tahsil.

The earlier studies, on the weed flora of the sugarcane fields and other crop fields have been made by different workers (Adlakha et al. 1971; Gill \& Singh, 1972; Mujumdar, 1962; Chakravarti, 1957; Patro, 1971; Diwakar, P. G. \& A. A. Ansari, 1995; Oudhia P. 2001; Sahu P. K. et al., 2010; Deokule S. S. \& Kamble S. Y. 1984; Mulay J. R. \& Sharma P. P. 2012; Prayaga M. P. et al., 2011; Bharttachrya et al., 2008) from different parts of India.

\section{MATERIALS AND METHODS:}

The exploration of the area under study includes the planned study tours to various places for crop weed collection. It was carried out during 2017-2020. The random sampling method was adopted for this study to note down the presence of herbaceous weed species among the irrigated and non-irrigated crop fields. Several field tours were made to cover the entire Daund Tahsil during rabbi as well as Kharif seasons. Collections were made from wide range of agricultural fields of Sugarcane, Jawar, Bajra, Cotton, Onion, Wheat, Gram, Vegetable crops, Groundnut etc. Notes were written on flower color, flowering and fruiting period, uses if any and general distribution.

After completing the herbaceous weed specimen collection from study area, herbariums of collected specimens were prepared (Jain S.K. and Rao R.R., 1978), (Diane B, Leonard F., 1998). Close up of flowering / fruiting material and habit along with associated plants were photographed. Special attention was paid to collect the plants from different areas and as far as possible all localities have been covered during all seasons. Extensive field work, exploration and collection of plants were carried out in different seasons. Identification of collected specimens was made with the help of relevant literature.

The laboratory work was mainly in the form of comprised the correct identification of collected specimens. The specimens were identified with the help of published flora like Flora of British India, Hooker J.D. (1898), Flora of presidency of Bombay, Cooke T. (1958) , The Flora of the Maharashtra state; Monocotyledons, Sharma B. D. et al (1996), Flora of Maharashtra State; Dicotyledons Vol I, Singh N. P. and Karthikeyan, S. (2001) , Flora of Maharashtra state Dicotyledons Vol- II , Singh, N. P. et al (2001). Flora of Kolhapur District, Yadav, S. R. and Sardesai M. M. (2002), 'Flora of Baramati', Bhagat, R.B. et al , (2008) , Flora of Khandala on the Western Ghats of India, Santapau, H., (1953), Flora of 
Purandar, Santapau, H. (1958), Botanical collectors' manual, Santapau, H. (1958) etc.

Names of the plant's specimens were searched concerning with the different herbaria especially Herbarium of Botanical Survey of India (B.S.I.), Western Circle, Pune, Herbarium, Department of Botany, Savitribai Phule Pune University, Pune, Agharkar Herbarium of Maharashtra Association (AHMA), Agharkar Research Institute (A.R.I.) Pune. The herbarium specimens of the collections have been deposited at the Herbarium, Department of Botany, E. S. Divekar College, Varvand, TalDaund, Dist- Pune (M.S.) India.

\section{RESULTS:}

The present investigation revealed that the total 60 herbaceous weed species belonging to 51 genera under 27 families growing in Daund Tahsil from Pune district (M.S.), India. Out of total 60 herbaceous weed species, 52 species, 44 genera \& 24 families belongs to Dicotyledons, while 8 species, 7 genera $\& 3$ families are of Monocotyledons. During the work it is observed that family. Asteraceae is dominant family of herbaceous weed species consisting of 10 species and 9 genera of area followed by Poaceae (6 species \& 5 genera), Amaranthaceae (5 species \& 5 genera), and Euphorbiaceae ( 5 species \& 4 genera) (Table No. 1). The floristic diversity of weed species is also analyzed with respect to habit diversity. Out of 60 herbaceous weed species 08 species are of grasses. The dominant weeds among weed flora of the area are Alternanthera sessilis (L.) R. Br., Boerrhavia erecta Linn., Cynadon dactylon (L.) Pers., Cyperus rotundus Linn. etc.

\section{DISCUSSION:}

The present information of herbaceous weed flora growing in Daund Tahsil is an important investigation and has applied significance in effective weed management and crop yield improvement process. The herbaceous weed flora work at regional level would be a good source of importance on technical and taxonomic data. The weed control problem is major challenge to the farmers because of increasing labor cost. However different parts of the weeds are very useful in various disorders. These weeds can become an additional source of income for farmers, if they are made aware about the medicinal utilities of these weeds. There is need to conduct proper study on the control of the population of these weed species within a plant population as well as their medicinal utilities.

\section{ACKNOWLEDGEMNTS:}

The authors, acknowledges their sincere and grateful thanks to Dr. L. K. Shitole, Principal, E. S. Divekar College, Varvand, Tal. Daund, Dist. Pune for their constant encouragements. They are also thankful to authorities of Department of Botany, Savitribai Phule Pune University, Pune and Botanical Survey of India (BSI), Western circle, Pune for their valuable guidance, constructive suggestions and laboratory facilities.

\section{REFERENCES:}

Adlakha, P. A., A. K. Shrivastava, S. S. Shirohi, \& V. K. Sharma, 1971. Weed Flora of Ludhiana, India. J. Weed Sci. 3: 37-44.

Bagal, J. G., S. S. Deokule and Ghalme, R. L. 2012. Assessment of floristic diversity of Daund Tahsil from Pune district (M.S.) 'Bionano Frontier' Vol-5(1): pp 63-65.

Bhattacharya, D. K. and P. C. Borah, 2008. Medicinal weeds of crop fields and role of women in rural health and hygiene in Nalbari District, Assam. Ind. J. Trad. Knowl. Vol 7(3), pp501-504. 
Bor, N.L.1960. The grasses of Burma, Ceylon, India ad Pakistan. Pergamon Flowers. London.

Chakravarti, A. K. 1957, Weed flora of paddy fields of West Bengal, Indian Agri. I (1), 1926.

Cooke T. (1901-1908). The flora of presidency of Bombay. Vol I-III, London. (Repr.ed.1958) B.S.I., Calcutta.

Diane B, Leonard F. (1998) The herbarium handbook (ed.) Royal botanical Gardens, Kew, UK.

Deokule, S. S. and Kamble, S. Y. 1984. Weeds of irrigated and non-irrigated agricultural fields of Baramati area in Pune district. $J$. Econ. Tax. Bot. Vol 1: 9-16.

Diwakar, P. G. and A. A. Ansari, 1995. Weed flora of Buldhana district, J. Econ. \& Tax. Bot. Vol. 19 (3), 607-610.

Hooker J. D. 1872-1897. The flora of British India, VII Vols. London.

Jain S.K. and Rao R.R. (1978) A Handbook of Field and Herbarium Methods. Today and tomorrow's Publication. New Delhi.

Mulay, J. R. and P.P. Sharma 2012. Some useful weeds from Ahamednagar District, Maharashtra, India. International Multidisciplinary Research Journal. 2(12) pp 05-08.

Oudhia, P. 2001, Medicinal weeds in Banana orchards: A Boon for small farmers of Chhattisgarh (India). Agri. Sci. Digest 21 (4), 267-268.

Patro, G. K. 1971, Survey of major distribution of used flora in four field's crops at
Bhubaneshwar area. Ind. J. weed Sci. 3: 104-111.

Prayaga Murty P. and M. Venkaiah 2011, Biodiversity of Weed species in crop fields of North coustal Andhara Pradhesh, India. Ind. J. Fund. and Appl.. Life Sciences Vol 1(2), pp.59-67.

Santapau, H. (1953) Flora of Khandala on the Western Ghats of India. Records of Botanical Survey of India.

Santapau, H. (1958) Flora of Purandar. Oxford Book and Stationary Company, New Delhi.

Santapau, H. (1958) Botanical collectors' manual. Botanical survey of India.

Sahu, Pankaj Kumar and Shrivastava Atul, 2010, Medicinal utilities of weed flora of agriculture field of JNKVV; Jabalpur, Int. Journal of Pharmacy and life sciences. 1(8): 448-450.

Sharma, B. D., Karthikeyan, S. and Singh, N. P. (Eds.) 1996. Flora of Maharashtra State Monocotyledons B.S.I., Culcutta.

Singh, N. P., Lakshminarsimhan, P. Karthikeyan, S. \& Prasanna, P. V. 2001. Flora of Maharashtra State Dicotyledons. Vol (2). Botanical Survey of India, Kolkata.

Singh, N. P., Karthikeyan, S. 2000. Flora of Maharashtra State Dicotyledons Vol (1). Botanical survey of India, Kolkata.

Yadav, S. R. and Sardesai M. M. (2002) Flora of Kolhapur District. Published by Shivaji University, Kolhapur- 416004. 
Table No.- 1. Records of Herbaceous Weed flora Growing in Daund Tahsil

\begin{tabular}{|c|c|c|c|c|}
\hline Family & Botanical Name & $\begin{array}{l}\text { Local } \\
\text { Name }\end{array}$ & F1. \& Fr. Period & Ref. No. \\
\hline \multicolumn{5}{|c|}{ I)DICOTYLEDONS } \\
\hline \multicolumn{5}{|c|}{ A)POLYPETALAE } \\
\hline Papaveraceae & Argemone mexicana Linn. & $\begin{array}{l}\text { Pivala } \\
\text { Dhotra }\end{array}$ & $\begin{array}{l}\text { Almost throughout } \\
\text { year }\end{array}$ & JGB-36 \\
\hline Brassicaceae & Thalspi arvense Linn. & Ran Mohari & Mar-April & JGB-212 \\
\hline Cleomaceae & Cleome gynandra Linn. & $\begin{array}{l}\text { Pandhari } \\
\text { Tilwan }\end{array}$ & June- September & JGB-47 \\
\hline Cleomaceae & $\begin{array}{l}\text { Cleome simplicifolia (Camb.) } \\
\text { Hook }\end{array}$ & --- & July.-Nov. & JGB-82 \\
\hline Cleomaceae & Cleome viscosa Linn. & $\begin{array}{l}\text { Pivali } \\
\text { Tilwan }\end{array}$ & June- September. & JGB-91 \\
\hline Polygalaceae & Polygala arvensis Willd. & --- & Jun.-Feb. & JGB-312 \\
\hline Portulacaceae & Portulaca oleracea Linn. & Ghol & Throughout year. & JGB-152 \\
\hline Portulacaceae & Portulaca quadrifida Linn. & Ranghol & Sept.-Feb. & JGB-122 \\
\hline Malvaceae & Sida acuta Burm. & Bala & Sept.-Feb. & JGB-6 \\
\hline Zygophylaceae & $\begin{array}{l}\text { Fagonia schweinfurthii } \\
\text { (Hadidi.) Hadidi. }\end{array}$ & Dhamasa & Oct.-Dec. & JGB-118 \\
\hline Zygophylaceae & Tribulus terestris Linn. & Sarata & Feb.-Nov & JGB-2 \\
\hline Oxalidaceae & Oxalis corniculata Linn. & Ambushi & Throughout year. & JGB-209 \\
\hline Sapindaceae & $\begin{array}{l}\text { Cardiospermum helicacabum } \\
\text { Linn. }\end{array}$ & Kapal phodi & July-Dec. & JGB-56 \\
\hline Fabaceae & Alysicarpus pubescens Law. & & Sept.-Dec & JGB-127 \\
\hline Fabaceae & $\begin{array}{l}\text { Crotalaria hebecarpa (DC.) } \\
\text { Rudd. }\end{array}$ & Godhadi & July-Feb. & JGB-92 \\
\hline Fabaceae & Cullen corylifolia (L.) Medik & Bavachi & Sept.-Jan. & JGB-124 \\
\hline Fabaceae & Indigofera cordifolia Heyne & Godhadi & July-Nov & JGB-273 \\
\hline Fabaceae & Indigofera glandulosa Wendl. & Barbada & Aug.-Nov & JGB-15 \\
\hline Cucurbitaceae & Mukia maderaspatana (L.) Roem & Tuntani & Sept.-Dec. & JGB-170 \\
\hline \multicolumn{5}{|c|}{ B) GAMOPETALAE } \\
\hline Asteraceae & Ageratum conyzodies L. & Osadi & Aug-Apr. & JGB-173 \\
\hline Asteraceae & $\begin{array}{l}\text { Bidens biternata (Lour.) Merr. } \\
\& \text { Scherif. }\end{array}$ & Chikta & Aug.-Oct. & JGB-42 \\
\hline Asteraceae & Caesulia axillaries Roxb. & Maka & Aug.-Feb. & JGB-81 \\
\hline Asteraceae & Emilia sonchifolia (L.) DC & Sadmandi & Aug.-Dec. & JGB-57 \\
\hline Asteraceae & $\begin{array}{l}\text { Flaveria trinervia (Spreng.) C. } \\
\text { Mohr. }\end{array}$ & Bajirao & Mar.-Apr. & JGB-78 \\
\hline Asteraceae & Lagascea mollis Cav. & --- & Throughout year & JGB-84 \\
\hline Asteraceae & $\begin{array}{l}\text { Launaea intybacea (Jacq.) } \\
\text { Beauv. }\end{array}$ & --- & Nov.-.Jan. & JGB-44 \\
\hline Asteraceae & $\begin{array}{l}\text { Launaea procumbens (Roxb.) } \\
\text { Ramayya }\end{array}$ & Pathri & Oct.-Feb. & JGB-153 \\
\hline Asteraceae & Sonchus asper (L.) Hill. & Mhatari & June-Oct. & JGB-154 \\
\hline Asteraceae & Tridax procumbens Linn & Kutkuti & Throughout year. & JGB-25 \\
\hline
\end{tabular}




\begin{tabular}{|c|c|c|c|c|}
\hline Apocynaceae & $\begin{array}{l}\text { Catharanthus pusillus (Murr.) } \\
\text { G. Don }\end{array}$ & --- & July-Oct. & JGB-176 \\
\hline Asclepiadaceae & $\begin{array}{l}\text { Pergularia daemia (Forssk.) } \\
\text { Chiov. }\end{array}$ & Utarni & July-Feb. & JGB-366 \\
\hline Boraginaceae & $\begin{array}{l}\text { Trichodesma indicum (Linn.) } \\
\text { Lehm. }\end{array}$ & --- & Aug.-Feb. & JGB-45 \\
\hline Convolvulaceae & Convolvulus arvensis Linn. & Chandvel & July-Mar. & JGB-117 \\
\hline Convolvulaceae & Evolvulus aslinoides (L.) L. & $\begin{array}{l}\text { Shankhapu } \\
\text { shpi }\end{array}$ & $\begin{array}{l}\text { Almost throughout } \\
\text { year. }\end{array}$ & JGB-133 \\
\hline Solanaceae & Physalis minima Linn. & Ran Popati & Oct.-Mar. & JGB-904 \\
\hline Scrophulariaceae & $\begin{array}{l}\text { Striga densiflora (Benth.) } \\
\text { Benth. }\end{array}$ & $\begin{array}{ll}-- \\
-1\end{array}$ & Oct-Jan & JGB-513 \\
\hline Scrophulariaceae & $\begin{array}{l}\text { Striga gesnerioides (Wild.) } \\
\text { Vatke }\end{array}$ & --- & Oct-Jan. & JGB-460 \\
\hline Lamiaceae & Leucas aspera (Willd.) Link. & Shankroba & Sept-Mar. & JGB-39 \\
\hline Lamiaceae & Leucas longifolia Benth. & Dudhani & Sept-Mar. & JGB-65 \\
\hline \multicolumn{5}{|l|}{ C) APETALAE } \\
\hline Nyctaginaceae & Boerhavia erecta Linn. & Punarnava & Sept.-Dec. & JGB-64 \\
\hline Amaranthaceae & Achyranthus aspera Linn. & Aghada & Oct. Mar. & JGB-61 \\
\hline Amaranthaceae & Alternanthera sessilis (L.) R. Br & Chimu-Kata & Throughout year. & JGB-123 \\
\hline Amaranthaceae & Amaranthus roxburghianus Nevski & Tandulja & June-Dec & JGB-221 \\
\hline Amaranthaceae & Digera muricata (Linn.) Mart. & Kunjir & June-Feb. & JGB-400 \\
\hline Amaranthaceae & Gomphrena serrata Linn. & $\begin{array}{ll}-- \\
-1\end{array}$ & June-Jan. & JGB-222 \\
\hline Aristolochiaceae & Aristolochia bracteolata Lam. & Badak Phul & July-Nov.JGB-309 & JGB-309 \\
\hline Euphorbiaceae & Chcrozophora rottleri (Gies.) Juss & --- & Nov.-May. & JGB-584 \\
\hline Euphorbiaceae & Croton bonplandianus Baill & Jamalgota & Aug.Jan. & JGB-627 \\
\hline Euphorbiaceae & Euphorbia geniculata Orteg. & Dudhani & Sept.-Mar.JGB-370 & JGB-370 \\
\hline Euphorbiaceae & Euphorbia hirta Linn. & Dudhani & $\begin{array}{l}\text { Throughout the } \\
\text { year. }\end{array}$ & JGB-203 \\
\hline Euphorbiaceae & $\begin{array}{l}\text { Phyllanthus madraspatensis } \\
\text { Linn. }\end{array}$ & --- & July-Dec. & JGB-581 \\
\hline Urticaceae & $\begin{array}{l}\text { Pilea microphylla (Linn.) } \\
\text { Liebm. }\end{array}$ & --- & Aug.-Dec. & JGB-595 \\
\hline \multicolumn{5}{|c|}{$\begin{array}{l}\text { II) } \\
\text { MONOCOTYLEDONS }\end{array}$} \\
\hline Liliaceae & Asphodelous tenuifolius Cavan. & --- & Nov.-Mar. & JGB-848 \\
\hline Cyperaceae & Cyperus rotundus L. & Lavala & June-Nov. & JGB-382 \\
\hline Poaceae & $\begin{array}{l}\text { Brachiaria eruciformis (J .E. } \\
\text { Sm.) Griseb. }\end{array}$ & Shimpi & Throughout year & JGB-250 \\
\hline Poaceae & Brachiaria ramosa (L.) Stapf & Chapar & Aug.-Oct. & JGB-372 \\
\hline Poaceae & Cynodon dactylon (L.) Pers. & Harali & Througout year. & JGB-59 \\
\hline Poaceae & Dinebra retroflexa (Vahl.) Panz. & Velu & Aug.-Feb. & JGB-860 \\
\hline Poaceae & $\begin{array}{l}\text { Eragrostis unioloides (Retz.) } \\
\text { Nees }\end{array}$ & --- & $\begin{array}{l}\text { Throughout the } \\
\text { year. }\end{array}$ & JGB-490 \\
\hline Poaceae & $\begin{array}{llll}\text { Setaria verticillata } & \text { (L.) } & \text { P. } \\
\text { Beauv. } & & & \\
\end{array}$ & --- & Aug.-Oct.JGB-317 & JGB-317 \\
\hline
\end{tabular}




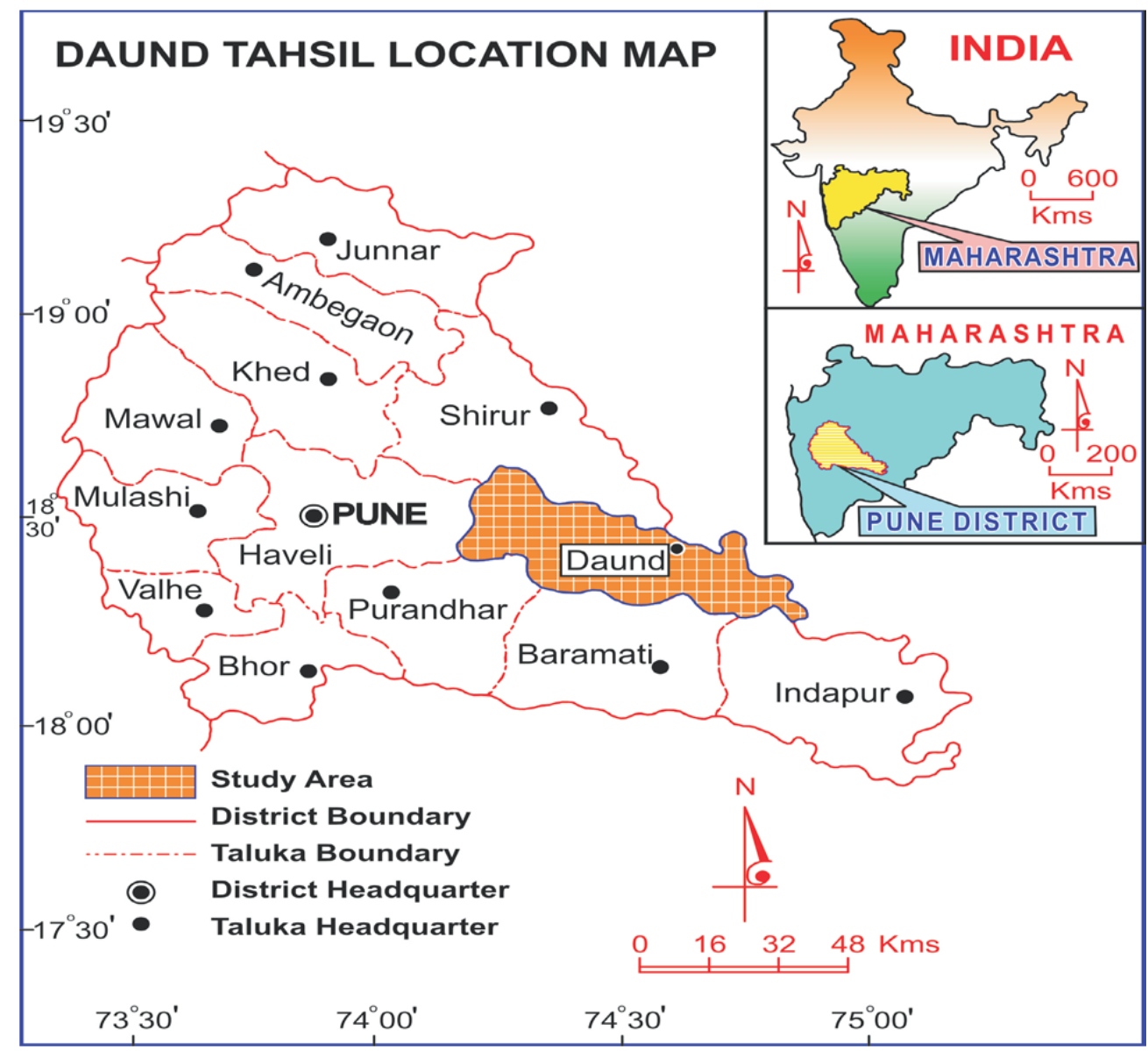

Map-1: Geographical location of Pune District in Maharashtra State (India) and Daund Tahsil in Pune district 